\title{
高齢者の健康評価をどのように行うか：HRV 研究を中心にして
}

\author{
道場 信孝 ${ }^{1)}$ 徳田 安春 ${ }^{2)}$ 久代登志男 ${ }^{3)}$ 日野原重明 1 )
}

1.はじめに

国際的に高齢化社会の時代に入った現状におい て，高齢者における健康の維持・増進は共通した健 康政策上の重要課題となっており, 費用/効果比を 含めたその有用性はお拈よそ認められる方向にあ る。従来，高齢者医療における健康評価では総合的 機能評価（CGA）が行われているが，一般の高齢 者を対象とする総合健診では異なった立場からの検 討が必要と思われる。

2000 年 9 月にライフ・プランニング・センター (LPC) では新しい老人の生き方を目指す「新老人 運動」が全国的な規模で開始され，現在の会員数は 1 万人を超えるに至っているが, 2002 年より「新老 人の会」に所属する会員の中から「脆弱化の進行に 関する研究」に自発的に参与する対象者を募り, 2005 年までの間に 408 名が登録された (エントリー 時の平均年齢 : $77.7 \pm 4.1$ 歳)。この研究は「Health Research Volunteer Study（HRV 研究）」と名付けら れ, 5 年間の前向き単一コホート研究 (観察研究) として開始されたが，今回は 2009 年 8 月までに検 討が終了した 318 例に関するデー夕を基に高齢者の 健康評価のあり方を考察したい。

\section{2. 脆弱化の考え方と捉え方}

脆弱化についてはいまだにその概念や診断には統 一された見解がない。Friedらは脆弱化 (frailty/ vulnerability）を臨床の表現型（phentype）として 捉える考えかたを示し, そのプライマリー・アプロー チとして frailty の診断基準を 6 項目にまとめた ${ }^{1) 。}$ これら frailtyの 6 項目中 3 項目以上を満たす群

1) 財団法人ライフ・プランニング・センター

2 ) 筑波大学大学院人間総合科学研究科臨床医学系水戸地域医療 教育センター

3 ) 日本大学医学部総合健診センター （frailty 陽性群）では 1 2 項目の中間群や 0 項目の 陰性群に比べて 7 年間の生存率が有意に低いことが 示されている。

これに対して Rockwood らのグループ（2005 年） は CSHA (Canadian Study for Health \& Aging) に おいて CSHA 臨床的脆弱スケールを7段階にカテ ゴリー化して示し，このようにしてカテゴリー化さ れた対象群の 70 か月（5.8 年）の生存率が $4 \sim 7$ 群 で 1 3 群より有意に低く，またナーシング・ホー ムなど高齢者施設への収容が 1 ～群より有意に高 くなることを示した ${ }^{2)}$ 。

以上のことから今回の研究では frailty の予測には 後者の基準を, そして frailty の病態生理学的検討に は前者の概念を適用することにした。

\section{HRV 研究の概要}

本研究の目的は，健康評価を身体的，心理・精神 的，社会的など生活の多元的側面について行うこと によって脆弱化のプロセスを明らかにし，その予防 的対応を模索することにある。全対象群は 407 例 [男 性 184 例：平均年齢 $78.2 \pm 4.5$ 歳（70 94 歳），女 性 223 例：平均年齢 $77.4 \pm 3.7$ 歳（70～91 歳)］よ りなり, 今回検討の対象としたのは 2002 年 11 月 5 日〜2004 年 3 月 3 日の期間にデータの集計が終了 した 318 例（男性 153 例，女性 165 例）である。対 象者の編入基準は新老人の会の会員であること，そ して, 全例について書面による承諾書を得た。研究 に対する倫理的承認は日本総合健診医学会倫理委員 会より得た。

調查の内容には以下の項目が含まれる：問診（問 診票：自己記入), 診察所見, 身体計測（身長, 体重, 体格指数, 体脂肪率, 上腕皮脂厚, 上腕周長, 上腕 筋囲，上腕筋面積，上腿周長，下腿周長），身体機 能検査 (握力, 四肢筋力, 歩行速度), 感覚系機能 (聴 力, 重心変動検査), 心藏・血管系機能 (動脈硬化 
の評価: PWV, AI, 上肢/下肢血圧比), 安静時代 謝率, 骨密度測定（DEXA 法による腰椎の骨密度）,

一般血液検查（総蛋白, アルブミン, 総コレステロー ル, HDL コレステロール, 血漿浸透圧, ナトリウム, カリウム, 尿素窒素, クレアチニン, CRP, へモグ ロビン $\mathrm{A} 1 \mathrm{c}$, 赤血球, 白血球, 血小板, ヘモグロビ ン, リンパ球数), 特殊検査（遊離テストステロン, 硫酸化デヒドロエピアンドロステロン, 黄体化ホル モン, コルチソール, インターロイキン-6, BNP), 遺伝子調查。生活調査票 (自己記入), うつ評価（自 己評価：Beckによる), 自己効力（自己評価：Banduraによる), 認知機能検查 (MMSE) : 看護師に よる評価, 食事調查（自己記入）。

研究期間は 5 年間で, 研究のエンドポイントは, 1）研究期間の終了時, 2）死亡, 3 ) 脆弱化（診 断基準による)，4）認知症，5）調查の中止：本 人の希望など。

\section{4. 調査結果}

\section{1 ）全体的評価}

5 年後にエントリー時と同様の検討が実施された 対象者は 213 例（男性 106 例，女性 107 例）, 紙面 調查が行われた者 13 例（男性 5 例，女性 8 例), 電 話調査が行われた者 17 例（男性 11 例, 女性 6 例), 脆弱化した者 30 例（男性 7 例，女性 23 例）, 死亡 した者 18 例（男性 11 例, 女性 7 例)，そして，脱 落者 27 例 (男性 13 例, 女性 14 例) で, 脱落率は $8.5 \%$ であった。死因の $50 \%$ は悪性腫瘍で, KaplanMeier法による生存曲線に性差は認められなかった。

2）脆弱化に関する結果

単変量解析で有意 $(\mathrm{p}<0.05)$ であった変数はパ ラメトリック項目では非脂肪量, 上腕筋面積, 腰骨 密度, 握力, 歩行速度, 収縮期圧, 脈圧, 脈波速度, 血色素, 黄体化ホルモン, そして, 非パラメトリッ ク項目では性, 記憶, 高コレステロール血症, 転倒, 配偶者, 尿失禁であった。

多変量 logistic regression モデルで有意であった 変数は非脂肪量, 上腕筋面積, 歩行速度, そして記 憶であった。

$3 ） 5$ 年の経過で有意に変化した評価項目は以下 の通りであった。

(1)身体計測：身長, 体重, 体脂肪率, 上腕周長, 上腕皮脂厚, 上腿周長, 下腿周長, 骨密度。

(2)機能検查 (一般): 握力, 平衡能, 歩行速度,
聴力。

(3)循環機器系能: 足腕血圧比, 脈波速度。

(4)血液検査：へモグロビン, 総コレステロール,

クレアチニン, 総タンパク, アルブミン, へモ

グロビン A1c，血清浸透圧，遊離テストステロ

ン, 黄体化ホルモン。

(5)その他: 生活態様, 自覚的体力能, 気力, 気分。

$4 ） 5$ 年経過後の心理・精神, 生活上の性差

MMSE の評価には性差がなく，Beck 法による評 価では女性でより「うつ」傾向がみられ，Bandura の自己効力は男性でより高い值が見られた。独居率 は男性で変化がなく, 女性では有意に高率となって いた。

\section{5 ）その他}

毎日外出する頻度は平地歩行能と体力の自己評価 に有意な関連が認められ，加齢とともに減少する傾 向にあった。気分（うつ的傾向）と食事の楽しみ, 気力と転倒には関連する傾向が見られた。

\section{5. 考案とまとめ}

高齢化した社会において脆弱化は医療と介護，そ して予防の観点から重要な健康障害の一つとみなさ れるが，我が国には脆弱化に関する大規模な前向き 研究はこれまで行われていない。本研究 (HRV研究) は単一コホートで少数例の前向き観察研究であり, なおかつ今回は中間的な報告であって結論を導き出 すには至らない。加えて脆弱化の定義や診断基準が 標準化されていないことから得られた結果を普遍化 するには多くの問題が存在する。本研究では医療的 観点からはRockwood らの脆弱化の層別化スコアを 用い，また脆弱化の病態機能的観点からは Fried ら の定義や診断基準を適用した。

これまでの結果を要約すると以下の通りである： (1) 5 年の経過で脱落率は 8.5\%であった。(2)死亡曲 線, 生存曲線に性差は認められなかった。(3)死亡原 因の $50 \%$ は悪性腫瘍であった。(4)脆弱化は女性で 多く見られた（3 倍)。(5)脆弱化に関連する要因： 非脂肪量, 上腕筋面積, 腰骨密度, HGD (握力 : 利き手), 歩行速度, 右腕 Ps (収縮期圧), 右脈圧, 右脈波速度, HGB (血色素), LH (黄体化ホルモン)。 (6)脆弱化の予測因子：上腕筋面積, 歩行速度, 脈圧, 記憶。(7)加齢を特徵づける形態的, 機能的変化が確 認された。8加齢に関わる検体検查の有用性が示唆 された：両性に有意なへモグロビンの低下，両性に 
表 1 高齢者の健康評価（案）

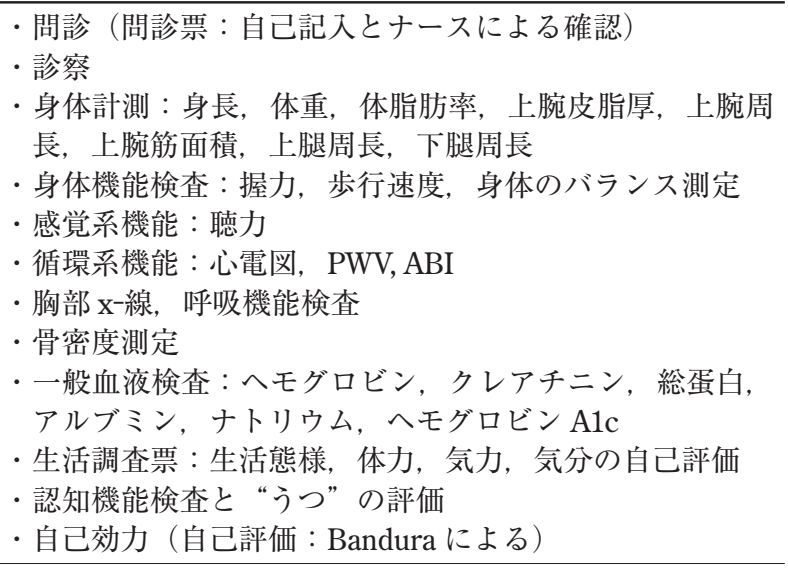

おける血清アルブミン值の低下，両性に見られるへ モグロビン A $1 c$ 值の上昇, 男性に見られる血清浸 透圧の上昇など。9 心理・精神, 身体機能に関する 自己評価は必要であり，かつ有用である。

その他，両性に有意なへモグロビンの低下，両性
における血清アルブミン值の低下，両性に見られる へモグロビン A1c 值の上昇, 男性に見られる血清 浸透圧の上昇など加齢に関わる脆弱化の促進要因が 認められ, さらに気力, 意欲, 体力, 記憶に関する 自己評価も脆弱化の評価に有用である可能性が示唆 された。これらの症状や徴候を適切に捉えて評価す ることにより, 高齢者やその家族, そして介護者に 有用な情報を与えながら問題の改善を図ることが今 後の総合健診医学に課せられた重要な課題であると 思われる。以上をふまえて高齢者の脆弱化を評価す る総合健診の案を表 1 に示した。

\section{参考文献}

1) Fried LP, Tangen CM, Walston J, et al. : Frailty on Older Adults : Evidence for a Phenotype. J Gerontol 56 : M146M156, 2001

2) Rockwood K, Song X, MacKnight C, et al. : A Global Clinical Measure of Fitness and Frailty in Elderly People. CMAJ. 173(5) : 489-495, 2005

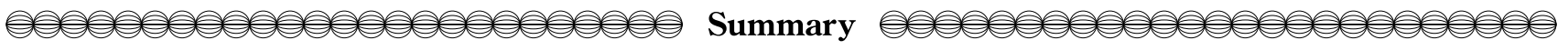

\title{
A Proposal for Health Evaluation of the Elder Based on the Preliminary Results from HRV Study
}

\author{
Nobutaka Dова, Yasuharu Toкuda, Toshio Kushiro, Sigeaki Hinohara
}

In the era of old age, health maintenance and promotion of the elderly has become one of the most important political issues throughout the world. Although the comprehensive geriatric assessment has now been a common approach in the clinical situation, there must be another strategy in the practice of Health Evaluation and Promotion. The Health Research Volunteer study has initiated in 2002 as a single cohort observational study to elucidate the process of frailty among 408 voluntary members belonging to the Association of New Elder Citizens started as a movement aiming to achieve the new lifestyle based on good living concept of Socrates. Preliminary results of the study obtained from 318 people will be presented in the symposium. Dropout rate of the study was $8.8 \%$ and 18 deaths $(6.2 \%)$ were observed. Frailty defined by the CSHA criteria was found in 30 subjects (10.3\%) and its incidence was three times more in females than in males. Multiple logistic regression analysis revealed four significant predictors for frailty including non-fat mass, upper arm muscle area, walking speed and self-assessment of cognitive decline. Other objective parameters associated with aging during 5 years observations also identified. Based on these findings, essentially minimum items for detection of frailty were proposed in the practice of health evaluation and promotion for the elderly. 